\title{
THE LOCAL KNOWLEDGE TRANSFER BASED ON CONTINUOUS IMPROVEMENT IMPLEMENTATION AT SMES GROUP
}

\author{
Elin Herlina ${ }^{1}$, Deden Syarifudin², Risna Kartika ${ }^{3}$ \\ ${ }^{1}$ Department of Management, Faculty of Economic, Universitas Galuh \\ email : elinherlina@unigal.ac.id \\ ${ }^{1}$ Department of Urban and Regional Planning, Faculty of Engineering, Universitas Pasundan \\ email : dden.syarifudin@unpas.ac.id \\ ${ }^{1}$ Department of Management, Faculty of Economic, Universitas Galuh \\ email : risnakartika@unigal.ac.id
}

\begin{abstract}
Article History :
Recieved 2 December 2018

Recieved in revished form

17 December 2018

Acepted 16 Januari 2019

Available offline 29 Januari 2019

Available online 30 Januari 2019
\end{abstract}

Language Transcript :

English (en)

Key Words :

Knowledge Transfer

Continuous Improvement

Implementation

SMEs Group

\begin{abstract}
This Paper is addressed to developing a knowledge transfer in the local contexed to implementation of continuous improvement (CI) on SMEs. The main problem of the research is how to developing the knowledge transfer model in the implementation of continuous improvement (CI) on SMEs in location at District of Cikoneng, Ciamis Regency. The concept of knowledge management and CI often cannot be rooted in local culture and knowledge, on the other hand it is more valuable to be implemented and evaluated in large companies than SMEs. However local knowledge is very valuable for local residents in increasing knowledge transfer and continuous improvement. Using a case study research approach, we managed to uncover the fact that local knowledge needs to be institutionalized to improve the sustainability of the company. There is a different work orientation and process between male and female employees, where men pay more attention to structured instruction compared to more informal women with different productivity. The CI model implemented must consider the process of their understanding and based on local knowledge, so that changes in mindset occur naturally can be found changes.
\end{abstract}

\section{INTRODUCTION}

SMEs center of Cikoneng Ciamis Regency is the competitiveness in West Java Province, as the economic center of snacks such as various kinds of processed crackers, macaroni, chips and others. Although the amount is not too large but has an impact on the economic improvement of the family in their live. As a reference data of PNKB Ciamis Regency in (2013), the number of snack centers in District Cikoneng there are 220 SMEs. From total of 220 SMEs, 98 SMEs partnered with Large Enterprises, the rest is an independent business in using input production, capital and labor and marketing. Based on data from center of statistics bureau of Ciamis Regency (2015) industrial centers in Cikoneng is a mainstay of ciamis district in developing the business and has a very wide impact for the development of the region. This sector contribution accounts for $11 \%$ of GNP, as well as $7 \%$ of employment in region of Ciamis Regency. 
Based on the research of continuous improvement (CI) implementation model at SMEs in Cikoneng Sub-district of Ciamis Regency (Herlina and Mulyatini, 2015), found problems that transfer knowledge from person/group to other person/group, and empirical observation from the role of library, center Information or documentation center and discussion room in the process of transfer of knowledge is very less. Some findings regarding the lack of deep knowledge transfer are as: [1]. Access to inadequate information that ignores the access center for new knowledge, then new knowledge can be based on the demand for new products from consumers; [2]. The ability to absorb the knowledge of personnel is less because it is shackled by routine in carrying out production; [4]. The learning ability is less a reflection of the lack of accepting new knowledge due to stickness or stickiness to old knowledge and not accepting new knowledge; [5]. The perception that exchange activities and knowledge combinations are valuable. One of the most important things is to feel the need for access to knowledge and exchange of information with other people or other companies do the personnel view this highly dependent on the demands of the company while the business owner regards the time not yet.

This research will developing knowledge transfer model in CI implementation, that is SMEs in Cikoneng District where in a model how is it necessary to discipline the organization to actualize it, among others by building a positive culture and learning climate, good leadership system, the availability of learning facilities Adequate, good learning programs, effective organizational infrastructure support in learning contexts, organizational vision and mission, shared values, organizational systems, and strategies for realizing a defined vision and mission. There are at least two things that affect the recipient's desire for the transfer of knowledge. The first knowledge of knowledge to be transferred and the second is the trustworthiness of the recipient.

The objectives of research conducted on SMEs in Kecamatan Cikoneng is as follows: [1] Identification of key factors that support knowledge transfer in SMEs; [2] Identification of knowledge transfer process in improving CI implementation to SMEs; [3] Knowing the knowledge transfer and linkage of learning processes in the CI process; [4] Developing a knowledge transfer model in the context of CI implementation of SMEs. This Reseach about knowledge transfer on CI implementation contributes to quality manajement and engineering form at SMEs level. The significance of this research is that SMEs can develop learning process that supports continuous improvement which in turn is able to adapt to internal and external environment and able to cooperate with Large SMEs.

\section{THE METHOD}

The process of knowledge transfer in Indonesia has not grown and developed well. This is due to: the lack of physical and financial facilities in the development of industrial research resulting in limited research and development activities, no good interaction between research institutions (higher education) with industry, research results PT (higher education) rare or not used by the industry because it is not in accordance with industry needs, Industrial culture in Indonesia who prefer to buy technology from abroad compared with doing their own technology (Daryanto, 2007). According to Irawati (2006), the problem of knowledge transfer in Indonesia is due to the fact that PT (higher education) only focuses on learning activities rather than 
research activities, some PT (higher education) has no research objectives or priorities, research funding is still minimal. Non-directional and overlapping research can be seen from the lack of scientific publications, research results that can not be utilized because they are inconsistent with the needs of users.

Srinivasan et.al (2004) describes the relationship between knowledge sharing and knowledge capture in supporting the increase of work productivity of employees in a company. While Hariharan (2005) focuses more on how to design a cycle of good knowledge management in an effort to obtain optimal results and a business both in terms of speed and consistency in consumer satisfaction. Knowledge Sharing can be said is one of the keys to the successful implementation of knowledge management both within organizations with large and small scale. Some of the research related directly or indirectly to this research include researchers from Bhirud et.al (2005) who discussed in detail about the techniques of implementing knowleadge sharing in practical knowledge management.

Table 1. Various Research Results

\begin{tabular}{|c|c|}
\hline Research View & Indicators \\
\hline $\begin{array}{lr}\text { Characteristics } & \text { and } \\
\text { Knowledge } & \text { Transfer } \\
\text { perspective } & \text { (Sugandhavanija, } \\
2010) & \end{array}$ & $\begin{array}{l}\text { The ability of SMEs to transfer knowledge; The adequacy of experts, } \\
\text { researchers and students; Adequacy of research equipment and equipment; } \\
\text { Willingness and motivation to cooperate and share knowledge } \\
\text { (Sugandhavanija, 2010) }\end{array}$ \\
\hline $\begin{array}{l}\text { Characteristics and Industry } \\
\text { Perspective (Sugandhavanija, } \\
\text { 2010) }\end{array}$ & $\begin{array}{l}\text { The ability of SMEs to receive knowledge transfer; Understand cultural } \\
\text { differences; Perspectives of feasibility and value of knowledge transfer in } \\
\text { economics; Willingness and motivation to work with universities and share } \\
\text { the benefits (Sugandhavanija, 2010); The closeness of the relationship (Goh, } \\
\text { 2002) }\end{array}$ \\
\hline $\begin{array}{l}\text { Knowledge Transfer } \\
\text { Mecanism } \\
\text { (Sugandhavanija, 2010) }\end{array}$ & $\begin{array}{l}\text { Effective communication; Coordination of office management and } \\
\text { knowledge transfer program; Learning process management and rewards } \\
\text { system (Sugandhavanija, 2010) }\end{array}$ \\
\hline $\begin{array}{l}\text { Infrastructure Support (Goh, } \\
\text { 2002) }\end{array}$ & Technology, Training, Skill Development. (Goh, 2002) \\
\hline $\begin{array}{l}\text { Type of Knowledge (Goh, } \\
2002)\end{array}$ & Tacit and explicit knowledge; Suitable transfer mechanism (Goh,2002) \\
\hline $\begin{array}{l}\text { Process Control (Molina et.al, } \\
\text { 2007) }\end{array}$ & $\begin{array}{l}\text { Process designed for quality; Products designed for quality; Employees who } \\
\text { are accustomed to using statistical control tools (Molina et.al, 2007) }\end{array}$ \\
\hline Leadership (Goh, 2002) & $\begin{array}{l}\text { Leadership willingness to share information and knowledge; The leader's } \\
\text { attention to solving organizational problems; Leaders' ability to encourage } \\
\text { employees to be involved (Goh, 2002) }\end{array}$ \\
\hline $\begin{array}{l}\text { Environment Uncertainty } \\
\text { (Liao dan Shu, 2007) }\end{array}$ & Complexity; Ambiguity; Protective Partners (Liao dan Shu, 2007) \\
\hline $\begin{array}{l}\text { The Effectiveness } \\
\text { Knowledge } \\
\text { Transfer(Sugandhavanija, } \\
\text { 2010) }\end{array}$ & $\begin{array}{l}\text { Growth of knowledge transfer from universities and industries; Performance } \\
\text { quality of knowledge transfer; Economic performance of knowledge transfer } \\
\text { (Sugandhavanija, 2010) }\end{array}$ \\
\hline $\begin{array}{l}\text { Competitive Advantage } \\
\text { (Liao dan Shu, 2007) }\end{array}$ & $\begin{array}{l}\text { Delivery accuracy; Supply complexity; Quality of service; product quality ( } \\
\text { Iuliana dkk, 2006). }\end{array}$ \\
\hline
\end{tabular}


This model looks more focused on the real problems that occur in the world of SMEs. In this model explained that the success of a production system at SMEs is not teriepas of a slick cooperation among the supporting elements, namely manager/owner, old employees and new employees. In some SMEs in Indonesia, supervisors can be regarded as experts both in terms of practical abilities and management abilities. This is because the production supervisor is selected from the worker is considered to have met certain criteria by the owner as having understanding of the production desired by the owner.

In addition to dependent on training activities both internal and external that are compulsory and routine, there are steps that would be assessed to be more effective result that is by way of knowledge sharing between new and old workers with the owner/supervisor. To maintain consistency and also to facilitate the process of knowledge sharing in order to continue continuously, it takes the process of documentation of all existing knowledge, both practical and theoretical. Here are some basic theoretical studies related to the research conducted as in Table 1 .

\section{RESULT AND DISCUSSION}

\subsection{SMEs Background}

Demographic characteristics of 20 SMEs entrepreneurs in Cikoneng District, Ciamis Regency, to be observed on knowledge transfer in CI implementation. SMEs entrepreneurs the average age is in the range of 30 years to 40 years. At that age psychologically the entrepreneurs already have long business experience to develop their business. In addition, entrepreneurs have a long business ranging from 10 years (70\%) while those with businesses of almost 20 years ranged from $24 \%$. This shows that SMEs entrepreneurs have long been involved in this business, so they understand how to run SMEs business and also do development and innovation in running their business. Furthermore, based on the level of education of SMEs entrepreneurs the average graduates of junior high school(38\%) and also senior high school (35\%), with experience between 10 years to 20 years.

3.2 Factors that support knowledge transfer to SMEs in Cikoneng District

1. SMEs as Family business. It is undeniable that the SMEs business in Cikoneng District is almost entirely a business involving children, wives, and extended families. Families not only as factors of production, but also have a role in determining whether SMEs succeeded even bankrupt. In direct observation can be seen the role of each family when deciding market or raw materials must be through mutual agreement. This process is not that easy sometimes to involve discussion, deliberation, but there are also some superior entrepreneurs all decided while others live obediently orders. Anyway in the family business, the husband as manager in running the business.

2. Unaccustomed to labels or markers and grouping of raw materials, production space, packaging and production storage space. In fact, the workers made an introduction to the equipment / tooling tools, goods and terms that are standard done in the company. The process of memorizing is not necessarily done, they traditionally introduce all the tools and goods as well as the parts that exist in the company "learning by doing". Based on the observation of some new workers they are still fresh in carrying out their obligations they will gladly accept knowledge transfer because they are very enthusiastic to anyone who gives knowledge to him. In a few months they are very quick to capture everything that 
happens, including within the work culture of SMEs.

3. Owners and workers who have long been a source of knowledge throughout the production process. It is understood that the source of knowledge, policies and rules are authorized by the owners of SMEs. While the operational execution authority is the employees who have long worked and follow the rules of business owners. Owners of SMEs and old workers who drive business and become a source of knowledge. In some other entrepreneurs the owner sometimes stuck running his business routine without any motivation to do the creativity of his business to survive and compete with other products.

4. Working as an obligation liability. Perhaps this is regarded as a weakness in running a business because there is no motivation that makes changes or improves skills that make the company more advanced and have a profit. Based on the observation it turns out the reality is different if our position is on the side of workers / employees, employee relations with SMEs owners there are 2 types of daily laborers and workers with monthly salary. For those who have a monthly salary are those who have kinship with the owner and have the authority in making decisions in accordance with the work he holds. Unlike employees who are paid with daily relationships with the management is a partnership, if it comes it will be paid and if it does not come work does not get wages. If so then everyone will do the same thing pragmatically, working to abort certain target obligations. But as long as the observations made in 20 SMEs interesting things even though they are only partnership relationship but SMEs company never lose its worker and they "faithfully" come every day work which show the existence of social power.

5. Orientation to production targets, not on quality. Observation of the basic case is that some SMEs doing business activities tend to decline. Other factors may have an external effect but they are well understood that they focus too much on order and production targets without developing an effective marketing system. The absence of networking or some cases is too obsessed with pursuing sales targets due to the high demand of some marketers. The impact is very easy once a competitor company hits such a company by offering several advantages such as good packaging, the quality of a grade product above it and a general acceptable taste.

\subsection{Process of knowledge transfer}

1. Owners and workers who have long been the source of knowledge of all employees in the whole process, the owner is basically as a teacher in running the business. Workers who have long worked are as accomplices of the owner in providing any knowledge to employees. The process of transfer of knowledge is not fixated on the conditions and time that has been specified. Situational is so flexible that it becomes a unifying force between tacit and explicit knowledge.

2. Experience as a knowledge. These words are common we hear how to transfer knowledge tacit and connect with eksplicit. The knowledge transfer process undertaken by SMEs in Cikoneng District mostly undertakes recruitment with unwritten agreements. Those who become employees are partners and not bound to work every day because it will be paid per day. Based on the observation of the same pattern and shape intended for new employees is the introduction of the 
environment, tools, machinery and terms that are done in the business while doing work guided by senior workers. The combination between expicit and tacit can easily be externalized in work activities. No other time is applied in improving their knowledge done during work.

3. "Ngawangkong" conversation in work as a knowledge transfer. One of the local traditions during work is 'Ngawangkong', ie chatting during a job where the other person is a friend, senior and even the owner who routinely runs the job. In the western state this activity is wasting time, but as it is observed in work, this process becomes a force in doing work for the employees and also the owner. This can be understood if not speaking in the work, or just listening to music, as if there is something missing in him and however the work becomes impeded because "Ngawangkong" gives the spirit to finish the job. Ngawangkong like have the power including improving the life skill of employees and increase motivation in work.

Based on the discussion of the approach taken in preparing the concept of the model is as follows:

1. The fact that the owner of the company as the initiator of the production process, has experience because as a worker in another company before starting a business so that it controls the whole process in running the business. The facts show that there is a relationship between lerning process conducted by SMEs with traditional knowledge transfer process tendency. In tranfer knowledge and IC the owner of the company must be a visionary person so running the model is right done by the owner of the company.

2. A worker is an unincorporated partnership relationship by the company, so the laerning process must be genetic without binding the workers.
3. Conduction and induction among workers, workers who have made a mistake are lucky workers because they will receive clear and detailed knowledge rather than obedient workers who work without problems. This is a contradiction if in large or multinational companies, workers who make mistakes are workers who do not learn. In fact, social forces and non-binding rules do not provide space for equality of knowledge transfer. This becomes an incentive for people who make mistakes, because it gets a lot of mentoring from seniors not to make mistakes.

\subsection{Generic Model}

The built model is to follow the basic model of the transformation of knowledge Nonaka (1991), Nonaka and Takeuci (1995) as a part of the cycle and not the stages in the managing process. The company is very influenced by the environment, therefore phasing is adjusted to the environment encountered in running the business. The built model has two sides: the managing process and the knowledge process, from the planning stage, the introduction, the increase in capital and the maturation stage. However, this model is still general and requires testing in its implementation as shown in Figure 1. 


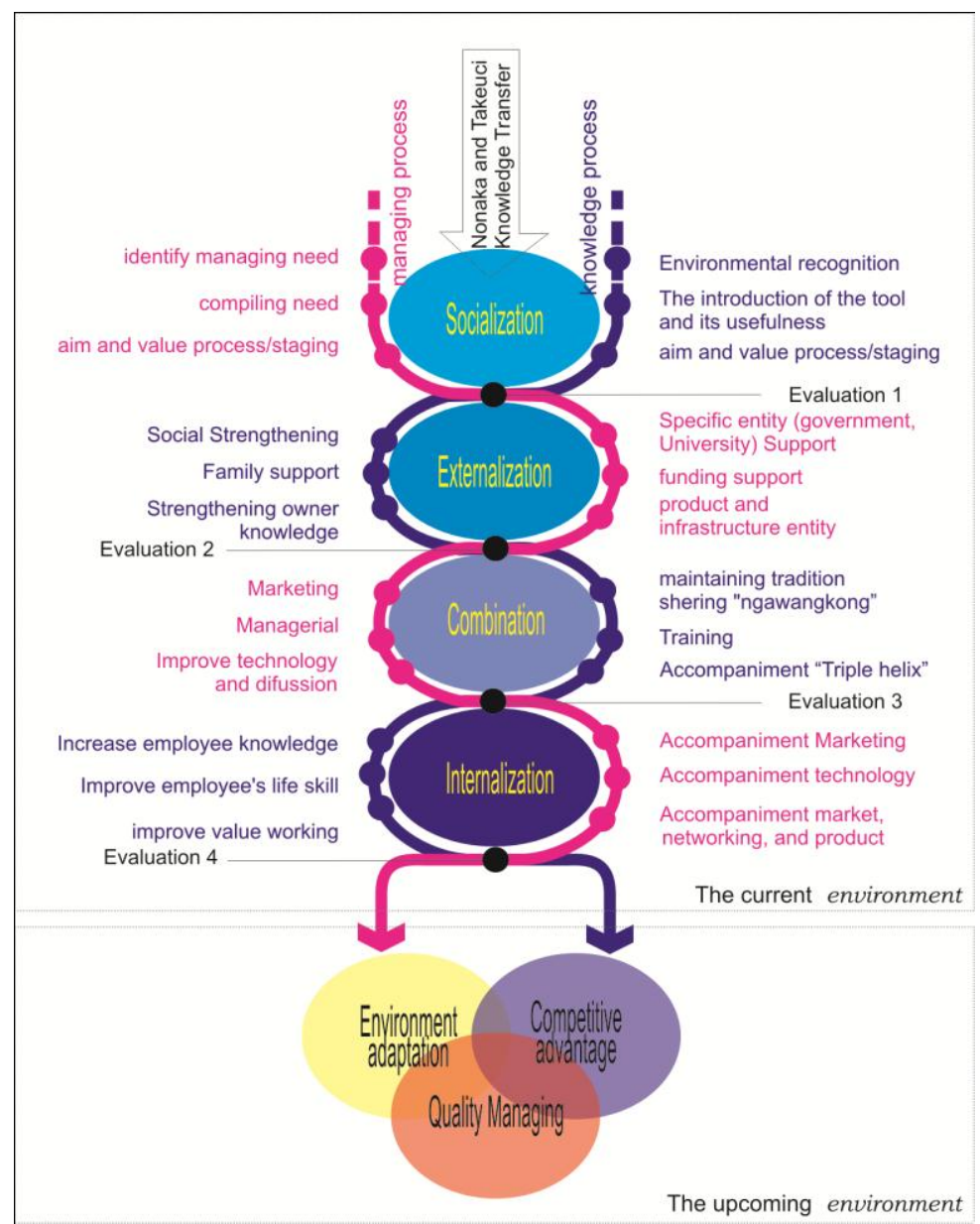

Fig. 1 Generic Model Knowledge Transfer Through Continuous Improvement

\section{CONCLUSIONS}

The result of this research is the key to SMEs entrepreneurs who want to make improvements to their companies to be more adaptive to change. This change is not only about changes in managerial but must be followed by changes and improvements to the knowledge transfer. Employers and senior workers should be teachers, visionary motivators. It is recognized that both SMEs workers and business owners need to improve their skills in line with SMEs business development. Traditional activities that have values in making continuous improvement and knowledge transfer need not be eliminated but become important boosters in keeping up with modern business changes.

\section{REFERENCE}

Bhirud et.al. (2005), Knowledge Sharing Practices In KM: A Case Study In Indian Software Subsidiary, Journal of Knowledge Management Practice, Desember 2005.

Daryanto, Arif. (2007), Industry Research Policy in Indonesia: Stagnation, Challenges and Opportunities. Nation al Conference Research and Technology Policy in Indonesia : challenge, stagnancy and opportunity, UNPAR, Bandung.

Goh, Swee C. (2002), Managing effective knowledge transfer: An integrative framework and some practice implication, Journal of Knowledge 
Management, Vol. 6 No.1, pp. $23-$ 30.

Hariharan, A. (2005). Critical success factors for knowledge management . Knowledge Management Review, Vol. 8 No2, pp.16-19.

Herlina, E. , Mulyatini, N., (2015), Continuous Improvement Model at UMKM in Cikoneng District of Ciamis Regency. Journal of Management Studies Program Econology Universitas Galuh Ciamis Vol 2 No 2 pp 91-109.

Irawati, Dessy. (2006), Understanding the Triple Helix Model from the Perspective of the Developing country : A Demand or a Challenge for Indonesian case Study?, Business School. Newcastle University.

Iuliana, Ciochin,. Manole Daniel Sorin., Decusear Rzvan. ( 2006), The Competitive Advantages of Small And Medium Enterprises, Faculty of Management Marketing in Business Affaires. University Pitesti.

Liao, Shu - Hsien dan Ta - Chien Hu. (2007), Knowledge transfer and competitive advantage on environmental uncertainty : An empirical study of The Taiwan semiconductor industry, Technovation, Vol.27, pp. $402-411$.

Molina, LM., Javier Llorens - Montes., Antonia Ruiz - Moreno. (2007), Relationship between quality management practices and knowledge transfer, Journal of Operation Management, Vol. 25, pp. $682-701$.

Nonaka, I. (1991), The KnowledgeCreating Company, Harvard Business Review, Vol. 69, pp. 96104.

Nonaka, I. and Takeuchi, H. (1995), The Knowledge-Creating Company: How Japanese Companies Create the Dynamics of Innovation, Oxford University Press, Oxford.

Sugandhavanija, P., Sukruedee sukchai., Nipon Ketjoy, sakol Klongboonjit. (2010), Determination of effective university - industry joint research for photovoltaic technology transfer (UIJRPTT) in Thailand, Renewable Energi, Vol. 36, pp. 600 -067.
Srinivasan, A. (2004), Use of Simulation Experiments To Evaluate Knowledge Management Modelling Quality, Journal of Knowledge Management Practice.

Yin, R.K., (1994), Case Study Research : Design and Methods, $2^{\text {nd }}$ edition, Sage Publications, Newbury Park.

Empowerment Board and Village
$\begin{aligned} & \text { Government } \\ & \text { Regency. }\end{aligned}$
Statistics (BPS), Ciamis Regency. 